\title{
Workshop Report
}

\section{Axis Empires. Toward a Global History of Fascist Imperialism \\ Center for Advanced Studies LMU Munich, 23-24 November 2015}

\author{
Giulio Salvati \\ Friedrich Schiller University Jena \\ giulio.salvati@katamail.com
}

\begin{abstract}
The international workshop organized by Daniel Hedinger and Reto Hofmann and financed by the Center for Advanced Studies at Ludwig Maximilian University in $\mathrm{Mu}$ nich brought scholars working on Axis countries together in order to explore viable approaches for a global history of fascist imperialism. The major questions addressed the colony-metropole relationship and its role in the radicalization process as well as the ways in which fascist empires learned from the imperial strategies used both by their allies and by their liberal-empire counterparts. In two days, the participants discussed how, when, and where these empires intersected, thereby investigating ideology, culture, empire-building processes and (self) perception.
\end{abstract}

\section{Keywords}

fascism - National Socialism - empire - imperialism - Axis - Japan - Italy - Germany

More than seventy years after the Axis powers were defeated, recent imperial and transnational trends in historiography offer us the opportunity to revise our understanding of fascism and, ultimately, of the Second World War as just

(C) SALVATI, 2016 | DOI 10.1163/22116257-00501005

This is an open access article distributed under the terms of the Creative Commons Attribution 3.0 Unported (CC-BY-NC 3.0) License. http://creativecommons.org/licenses/by/3.0/ 
a conflict among nations. In 2008 Mark Mazower published the book Hitler's Empire in which he presented the Nazis' vision of German hegemony as an empire-building process. ${ }^{1}$ More recently, Ruth Ben-Ghiat's book on Italian Fascism's Empire Cinema breaks with previous studies by focusing on imperial visions and themes. ${ }^{2}$ While imperial concepts have become established as valuable categories with which to harmonize the discrepancies between the ideological visions and realization, scholars have focused mainly on single cases. In this context, the space 'in-between' fascist empires remains largely unexplored, and the workshop was able to elaborate innovative strategies to fill this gap.

The first panel on 'Comparative Perspectives' investigated how to operationalize and understand fascism and imperialism as analytical categories. LOUISE YOUNG (Madison) demonstrated the different logics underlying both of these as they pertain to the Japanese case. The construction of a colonial empire in Asia was only made possible by increasing militarism and anti-communism; however, as she pointed out, they were not an expression of fascism per se. Several internal and external crises were necessary to fuel and realize Japan's expansionist ambitions. The crises, as RETO HOFMANN (Melbourne) presented, revealed the use of imperialism and fascism as 'corrective imperatives' in order to fix the relationship between nation and capital. As a result, Japan's imperialism pushed towards fascism once the former revealed itself to be insufficient to solve the crisis, while the opposite happened in Germany and Italy. The resulting imperial expansions were connecting moments for the fascist empires, which DANIEL HEDINGER (Munich) identified as 'imperial nexus.' Japan's expansion in Manchuria and Italy's occupation of Ethiopia drew the attention of the other nations and prompted the fascist empires to interact and collaborate, which, in turn, enabled the creation of the AntiComintern Pact. In his comment, sven REICHARDT (Konstanz) suggested that fascism, in this context, be considered a process rather than a monolith, thus encouraging scholars to develop the implicit definitions presented in their papers.

The second panel was organized around the theme 'Ideological and Cultural Connections' and revealed the importance of culture and ideology for the imperial projects. Transnational transfer played a crucial role which helped overcome deep-rooted ideological differences. The lateness with which Germany and Italy became empires led to a strong cultural imperialism, argued BENJAMIN MARTIN (Uppsala) in his presentation. The newcomers undertook

1 Mark Mazower, Hitler's Empire: Nazi Rule in Occupied Europe (London: Allen Lane, 2008)

2 Ben-Ghiat, Italian Fascism's Empire Cinema (Bloomington: Indiana University Press, 2015) 
imperial projects that they formulated as 'anti-civilizational critique' against the British and French universalistic cultural values, which they then labeled as declining models - a strategy resembling Japan's own imperial efforts. However, the transmitted ideologies represented a constant dividing factor inside the alliance. Following the worldviews of the leading Japanese and German politicians, GERHARD KREBS (Berlin) noted that the partnership between both empires was marked by ideological contradictions on both sides - for Japan it was a cooperation with the abhorred 'white man' and for Germany, an alliance with the racially inferior 'yellow hordes.' In practice, fascist movements were eager to adopt their co-fascists' strategies, as TATIANA LINK HOEVA (Munich) pointed out. Italian Fascism was transported into Japan in 1923 when the Statecraft Study Association was founded. By merging socialist and nationalist ideas, it became the birthplace of later ultra-nationalist organizations. MARTIN BAUMEISTER (Rome) commented that, despite the different understandings, all papers came to the conclusion that, above all, culture represented a dividing factor among the empires.

In the evening, VICTORIA DE GRAZIA (New York) gave a keynote speech on the imperial struggle for hegemony in the Mediterranean. She explored the characteristics of Italian colonialism and its relationship to the existing international order by illustrating the career of Attilio Teruzzi, the Fascist minister of the colonies. For De Grazia, the main peculiarities of Italian colonialism consisted of the blurred sovereignty over the colonies, its co-existing Catholic imperialism, and the pre-existing 'Greek-style' colonies around the globe, meaning the Italian communities found in various countries that sought to maintain strong ties to Italy.

The next day, the third panel on 'Empire Building' questioned how imperial visions were developed in collaboration and in competition with the other fascist empires. In this context, racism was not merely a point of difference but also a point of intersection, as was demonstrated by PATRICK BERNHARD (Potsdam) through Germany's keen interest in Italy's colonial project. Italy's colonial experience was communicated through several channels and influenced Berlin's imperial vision in Eastern Europe as part of a competition that ultimately led to the radicalization of both empires. JANIS M IMURA (New York) explored the often neglected Japanese puppet state Manchukuo and its role as 'incubator' for Axis relations after the country signed the first Anti-Comintern Pact alongside Germany and Japan in 1936. In Manchukuo, diplomats and businessmen nurtured closer relations that resulted in the redirecting of Germany's economic and political interests away from China. MONICA FIORAVANZO (Padua) could not attend the conference, but the paper she submitted offered interesting insights into the changing European order as envisioned by Italian 
Fascism. Again, the Italian vision remained in constant competition with Germany's expectations during the war. This resulted in an open conflict between the two until 1943, when the weak Italian partner finally subjugated itself fully to German claims. XOSE MANOEL NENEZ SEIXAS (Munich) responded by noting the necessity to investigate further mediators, such as career diplomats and their role in a model of fascist imperialism.

The next panel on 'Regionalizing Axis Imperialism' offered new approaches on the peripheries of fascist empires, which were subject to very specific regimes but were also points of intersection between empires. In Southeast Asia, the intensified cooperation between Germany and Japan in providing natural rubber from the former Dutch colonies under Japanese occupation was described by rotem коWner (Haifa). The technical assistance that Germany provided in exchange intensified cooperation and led unexpectedly to more explicit anti-Jewish measures in the region. However, policies were also affected by the peripheries of the other empires, as KELLY HAMMOND (Fayetteville) examined for the Japanese case. Japan was interested in Italy's colonial experience in Africa because it was considered as a viable model that could be used to assure control over the Muslim population in China and as a strategy to improve relationships with Middle Eastern countries. SANELA SCHMID (Nuremberg) demonstrated how the concept of fascist empire is able to explain the contradictions of Italy's failed occupation policy in Croatia. The Italian Army followed the principles of 'imperial justice' and 'imperial strength,' which led to protecting its subjects from the German ally while undertaking bloody and violent counterinsurgency measures in the area. RICHARD BOsWORTH (Oxford) problematized the use of Romanità as a comparative category that refers to the Roman Empire as the core idea embedded in every imperial project.

The final panel on 'The World and the Axis' investigated how intellectual and political discourses perceived fascist empires from the outside and influenced them from the inside. KILIAN BARTIKOWSKI (Lancaster) explored the fragmented British perception of the Italian invasion in Ethiopia and illustrated how pro-colonialist and anti-imperialist positions both welcomed and condemned the imperial project at the same time. SHOSHEI SAITo (Munich) turned to Eurasianism as an ideology claimed by several groups. First it was used by the Russian community in Manchukuo to defend its cultural identity against Japan and then by the Japanese imperial project, which tried to implement it into its own ideological framework to control the various minorities. LAURA CERASI (Venice) analyzed the ambivalent relationship between the British Empire and Italy from a historical perspective. She discovered that, despite the competitive attitude during the war, fascist imperialism considered the British Empire as a successful role model; fascists 'talked empire' as a strategy emulating Great Britain. ANDREAS RENNER (Munich) pointed out 
the necessity to formulate valid typologies for 'fascist empire' in contrast to 'liberal empire' and provokingly asked if the British Empire could be placed in the first category because of its shared assumptions on colonial racism with fascism.

Finally, the workshop showed that fascist empires cannot be analyzed from a purely national perspective but should be seen as having been in constant dialogue with each other and with the wider world. As many younger scholars demonstrated, relevant interactions took place at various levels. Also, the contacts between fascist empires were not limited to traditional diplomatic and political channels. Rather, we see a plethora of new ties that permitted a constant exchange around the globe. The participants of the workshop also revealed how cooperation and competition were interconnected. Imperial visions were global visions, and all fascist states competed against each other in creating new ones. As a side effect, the rivalry triggered manifold processes of radicalization. Competition and radicalization paradoxically resulted in strengthening the ties between fascist empires, ultimately allowing them to challenge the 'dominant' liberal world order. In this sense, a cultural history approach can contribute to a better understanding of the global dimension of these empires by asserting how differently the relationships between fascist nations were perceived by the fascists themselves and by their liberal counterparts at various times and, finally, how the perception affected decisionmaking. This allows scholars to move beyond the problem of 'objective' differences and essential features of these regimes. Therefore, as an analytical category, 'fascist empire' allows us to re-conceptualize the history of fascism and the Second World War from a global perspective.

\section{Conference Overview}

Monday, 23 November 2015

Daniel Hedinger (Munich), Reto Hofmann (Melbourne): Welcome address

\section{Panel 1 - Comparative Perspectives}

Louise Young (Madison): Fascist Imperialism / Imperial Fascism / Japan and Asia

Reto Hofmann (Melbourne): The Corrective Imperative. Fascism Between Nation and Capital

Daniel Hedinger (Munich): The Imperial Nexus. The Berlin - Rome - Tokyo Axis and the Second World War in a Colonial Context Sven Reichardt (Konstanz): Commentary 


\section{Panel 2 - Ideological and Cultural Connections}

Benjamin Martin (Uppsala): Culture and Fascist Imperialism. Cultural Politics of Empire in and between Italy and Germany 1935-1945

Gerhard Krebs (Berlin): The Yellow Peril Revived. Nazi Germany and the Japanese Domination over Asia

Tatiana Linkhoeva (Munich): Debates on 'Japanese-style Fascism' in the 1920s Martin Baumeister (Rome): Commentary

Keynote Lecture

Victoria de Grazia (New York): Imperialism versus Imperialism? The European New Order's struggle against the Anglo-American Colonial Order in the Mediterranean and East Africa

Tuesday, 24 November 2015

\section{Panel 3 - Empire Building}

Patrick Bernhard (Potsdam): The Missing Link. Italian Colonialism as an Inspirational Force for the Nazis' Dream of Empire Janis Mimura (New York): Manchuria and the Axis Alliance Monica Fioravanzo (Padua): The Dream of the 'Euro-Afro-Asiatic Vital Space'. Italian Fascism and the Idea of a New European Order 1932-1945

Xosé Manoel Núñez Seixas (Munich): Commentary

\section{Panel 4 - Regionalizing Axis Imperialism}

Rotem Kowner (Haifa): When Economy, Strategy and Racial Ideology Meet. Inter-Axis Connections in Southeast Asia

Kelly Hammond (Fayetteville): Managing Muslims. Japan's Quest to Legitimize Itself in the Islamic World through Connections with Italy and Germany in WWII

Sanela Schmid (Nuremberg): Italian Empire-Building and German Observances in the 'Independent State of Croatia'

Richard Bosworth (Oxford): Commentary

\section{Panel 5 - The World and the Axis}

Kilian Bartikowski (Lancaster): British Observations on the 'New' Italian Colony Abyssinia

Shohei Saito (Munich): Crossing Perspectives in Manchukuo: Russian Eurasianism and Japanese Pan-Asianism

Laura Cerasi (Venice): Defining Fascist Imperialism Between the Legacy of Rome and Visions of the British Empire

Andreas Renner (Munich): Commentary 